\title{
THE IMPROVEMENT OF OBSERVATION REPORT WRITING SKILL THROUGH THE APPLICATION OF THINK PAIR SHARE LEARNING MODEL
}

\author{
Widya Atika, Sukarno, Siti Wahyuningsih
}

Universitas Sebelas Maret

attikawidya@gmail.com

\section{Article History}

accepted 09/07/2018

approved 01/08/2018

published 17/09/2018

\section{Keywords}

Think Pair Share, writing skill, observation reports writing skill

\begin{abstract}
The objective of this research is to improve the observation reports writing skill through Think Pair Share Learning Model on $5^{\text {th }}$ grade students. The subjects of this research are teachers and students of $5^{\text {th }}$ grade. This research is a classroom action research which is conducted in two cycles. The techniques of collecting data which used test, observation, interview, and documentation. The date analysis used is interactive analysis model. Validity of data used content validity and technique triangulation. The result of this research is classical completeness on pre-action is $35 \%$, on cycle I the classical completeness increases to $70 \%$ and on cycle II the classical completeness increases to $85 \%$. Based on the results of this research it can be concluded that through the application of Think Pair Share learning model, it can improve the observation reports writing skill $5^{\text {th }}$ grade students.
\end{abstract}

Social, Humanities, and Education Studies (SHEs): Conference Series https://jurnal.uns.ac.id/shes
p-ISSN 2620-9284 e-ISSN 2620-9292 


\section{PENDAHULUAN}

Seseorang seringkali memiliki keinginan untuk menulis, tetapi mereka sulit menuangkan isi pikiran dan perasaannya dalam bentuk tulisan, sehingga mereka menganggap menulis adalah hal yang sulit. Sejalan dengan pendapat Kusumaningsih, dkk (2013: 66) yang menyatakan bahwa menulis itu adalah hal yang sulit, kegiatan menulis perlu mendapatkan bimbingan. Menulis bukan sekedar menghasilkan bahasa tetapi bagaimana menuangkan ide dan gagasannya serta mengorganisasikannya dalam ragam bahasa tulis yang sesuai dengan aturan. Ada banyak hal yang harus diperhatikan dalam menulis, sehingga pesan yang dituliskan oleh penulis dapat tersampaikan.

Tugas menulis identik dengan kegiatan belajar, baik di sekolah, khususnya dalam mata pelajaran Bahasa Indonesia. Mata pelajaran Bahasa Indonesia di sekolah dasar terdiri atas 4 keterampilan berbahasa. Tarigan (2013: 1) mengungkapkan bahwa keterampilan berbahasa memiliki 4 aspek keterampilan yang mencakup dalam pengajaran bahasa adalah: (1) keterampilan menyimak (listening skills); (2) keterampilan berbicara (speaking skills); (3) keterampilan membaca (reading skills); dan (4) keterampilan menulis (writing skills). Keterampilan menulis merupakan keterampilan berbahasa yang paling akhir dikuasai oleh pembelajar bahasa setelah keterampilan menyimak, berbicara dan membaca.

Salah satu standar kompetensi yang ada pada silabus KTSP 2006 Tingkat sekolah dasar kelas $\mathrm{V}$ pada pembelajaran Bahasa Indonesia adalah kompetensi menulis laporan pengamatan atau kunjungan berdasarkan tahapan (catatan, konsep awal, perbaikan, final) dengan memperhatikan penggunaan ejaan. Nurgiyantoro (2009: 302) menjelaskan bahwa kaitannya dengan pengajaran bahasa, menulis laporan dapat dimanfaatkan untuk melatih dan mengungkapkan kemampuan menulis siswa.

Berdasarkan wawancara yang dilakukan dengan guru SD N di Surakarta diketahui bahwa mayoritas anak mengalami kesulitan dalam menuangkan gagasan dan merangkai kata. Selain itu, anak-anak juga belum menguasai penggunaan ejaan dan tanda baca. Selama pembelajaran menulis guru sudah melibatkan siswa secara aktif namun belum menyeluruh. Peneliti juga melakukan wawancara dengan siswa, dari wawancara dengan siswa diperoleh kesimpulan bahwa siswa ku-rang menyukai pelajaran Bahasa Indonesia karena mengalami kesulitan dalam me-rangkai kata. Berdasarkan proses observasi, peneliti menemukan fakta bahwa guru masih teoriti dan siswa kurang mendapatkan pengarahan dan bimbingan dalam proses menulis yang benar. Selain itu, pembelajaran kurang inovatif sehingga siswa belum aktif secara menyeluruh.

Hal tersebut berdampak pada nilai keterampilan menulis laporan pengamatan siswa. Dibuktikan dengan nilai prasiklus siswa pada keterampilan menulis laporan pengamatan, tercatat $35 \%$ atau hanya 7 siswa dari 20 siswa yang mampu mencapai Kriteria Ketuntasan Minimal (KKM) yaitu sebesar 75. Artinya masih terdapat $65 \%$ atau 13 siswa yang belum mencapai KKM. Fakta tersebut merupakan indikasi bahwa proses pembelajaran yang dilakukan kurang berhasil dalam meningkatkan keterampilan menulis laporan pengamatan.

Alternatif solusi terhadap masalah rendahnya keterampilan menulis laporan pengamatan adalah penggunaan model pembelajaran inovatif. Salah satu model pembelajaran yang dapat diterapkan adalah Think Pair Share Alasan digunakan model pembelajaran Think Pair Share dalam peningkatan keterampilan menulis laporan pengamatan karena dapat membantu siswa untuk berpikir dalam mengumpulkan informasi, berdiskusi dan membantu siswa lain agar terampil dalam menulis.

Model Think Pair Share terdapat 3 langkah inti menurut Hamdayama (2015: 201) yaitu thinking, pairing dan sharing, yang artinya berfikir, berpasangan dan 
berbagi. Melalui tahap Think dalam model ini, siswa dikondisikan untuk berfikir menemukan ide atau gagasan yang akan ditulis siswa berdasarkan pengamatannya. Dilanjutkan kegiatan Pair yaitu mengungkapkan hasil pemikirannya bersama temannya secara berpasangan kemudian dituangkan dalam bentuk tulisan. Melalui proses tersebut siswa dapat mengembangkan ide yang ada dalam pikirannya berdasarkan apa yang sudah diamati dan dialami bersama dengan temannya. Setelah itu, pada tahap Share siswa bertemu dengan pasangan lain untuk saling berbagi apa yang telah mereka bicarakan. Hal tersebut, memberi kesempatan kepada siswa untuk untuk saling berbagi informasi, saling memberi saran dan melakukan perbaikan tulisannya. Selain itu model Think Pair Share merupakan suatu model yang efektif untuk mengubah suasana diskusi kelas (Fathurrohman, 2015: 86 ).

\section{METODE}

Penelitian ini merupakan jenis penelitian tindakan kelas yang dilaksanakan secara bersiklus. Penelitian tindakan kelas dilaksanakan di dalam kelas berupa tindakan nyata terhadap kegiatan belajar-mengajar untuk memperbaiki dan meningkatkan kondisi pembelajaran (Iskandar, 2009). Penelitian ini dilaksanakan di SD Negeri di Surakarta tahun ajaran $2017 / 2018$. Subjek penelitian ini adalah guru kelas V dan siswa kelas V. Penelitian dilaksanakan selama delapa bulan mulai dari bulan Desember 2017 hingga Juli 2018.

Data yang dikumpulkan dalam penelitian ini berupa hasil observasi kinerja guru dan aktivitas siswa, hasil wawancara guru dan siswa, hasil tes pratindakan dan hasil tes pada setiap pertemuan pada siklus I, dan II, serta dokumentasi selama proses pembelajaran. Sumber data dalam penelitian ini yaitu sumber data primer dan sekunder. Teknik pengumpulan data yang digunakan yaitu observasi, wawancara, tes, dan dikumentasi. Validasi data yang digunakan yaitu validasi isi dan triangulasi teknik. Data yang diperoleh dalam penelitian ini dianalisis menggunkan model interaktif Milles dan Huberman yang dilakukan dalam 2 siklus dengan masing-masing siklus terdiri dari 2 pertemuan. Setiap siklus terdiri atas 4 tahap yaitu perencanaan, tindakan, observasi dan refleksi

\section{HASIL DAN PEMBAHASAN}

Sebelum melaksanakan tindakan, peneliti melakukan kegiatan wawancara, observasi, dan memberikan pretes pada siswa. Hasil pretes tersebut menunjukkan bahwa sebanyak 13 siswa atau 65\% nilai keterampilan menulis laporan pengamatan siswa masih di bawah KKM (75), serta nilai rata-rata ketuntasan klasikalnya hanya $35 \%$ (rendah). Hasil selengkapnya dapat dilihat pada Tabel 1 sebagai berikut: 
Tabel 1. Hasil analisis Keterampilan Menulis Laporan Pengamatan Pratindakan

\begin{tabular}{|c|c|c|c|c|}
\hline \multirow[t]{2}{*}{ Interval } & \multirow{2}{*}{$\begin{array}{c}\text { Nilai Tengah } \\
(\mathrm{x})\end{array}$} & \multirow{2}{*}{$\begin{array}{l}\text { Frekuensi } \\
\text { (f) }\end{array}$} & \multicolumn{2}{|c|}{ Persentase (\%) } \\
\hline & & & Relatif & Kumulatif \\
\hline $30-39$ & 34,5 & 2 & 10 & 10 \\
\hline $40-49$ & 44,5 & 5 & 25 & 35 \\
\hline $50-59$ & 54,5 & 2 & 10 & 45 \\
\hline $60-69$ & 64,5 & 3 & 15 & 60 \\
\hline $70-79$ & 74,5 & 5 & 25 & 85 \\
\hline $80-89$ & 84,5 & 3 & 15 & 100 \\
\hline \multicolumn{2}{|c|}{ Nilai Tertinggi } & \multicolumn{3}{|c|}{85} \\
\hline \multicolumn{2}{|c|}{ Nilai Terendah } & \multicolumn{3}{|c|}{30} \\
\hline \multicolumn{2}{|c|}{ Nilai Rata-rata } & \multicolumn{3}{|c|}{60,28} \\
\hline \multicolumn{2}{|c|}{ Ketuntasan Klasikal } & \multicolumn{3}{|c|}{$35 \%$} \\
\hline \multicolumn{2}{|c|}{ Nilai dibawah 75} & \multicolumn{3}{|c|}{13} \\
\hline
\end{tabular}

Berdasarkan Tabel 1 mengenai distribusi frekuensi nilai keterampilan menulis laporan pengamatan pada tahap pratindakan siswa kelas V SD N di Surakarta menunjukkan nilai tertinggi keterampilan menulis laporan pengamatan adalah 85 dan nilai terendah adalah 30 . Nilai rata-rata menulis laporan pengamatan siswa adalah 60,28 . Persentase ketuntasan klasikal sebanyak 35\% sedangkan persentase nilai dibawah KKM (75) atau belum tuntas sebanyak 65\%.

Setelah dirterapkannya model Think Pair Share dalam proeses pembelajaran, nilai keterampilan menulis laporan pengamatan pada siklus I mengalami peningkatan. Hasilnya dapat dilihat pada tabel 2 sebagai berikut:

Tabel 2. Hasil Analisis Nilai Keterampilan Menulis Laporan Pengamatan Siklus I

\begin{tabular}{lcccc}
\hline Interval & $\begin{array}{c}\text { Nilai Tengah } \\
\text { (x) }\end{array}$ & $\begin{array}{c}\text { Frekuensi } \\
(\mathbf{f})\end{array}$ & & \multicolumn{2}{c}{ Persentase (\%) } \\
\cline { 4 - 5 } & 2 & 45,5 & 10 & 10 \\
\hline $42-49$ & 1 & 53,5 & 5 & 15 \\
$50-57$ & 2 & 61,5 & 10 & 25 \\
$58-65$ & 1 & 69,5 & 5 & 30 \\
$66-73$ & 10 & 77,5 & 50 & 80 \\
$74-81$ & 4 & 85,5 & 20 & 100 \\
$82-89$ & & 87,5 & \\
\hline Nilai Tertinggi & & & 42,5 & \\
\hline Nilai Terendah & & & 72,25 \\
\hline Nilai Rata-rata & & $70 \%$ & \\
\hline \multicolumn{2}{l}{ Ketuntasan Klasikal } & & 6 \\
\hline \multicolumn{2}{l}{ Nilai dibawah 75 }
\end{tabular}


Pada silklus I diperoleh nilai rata-rata 72,25 . Ketuntasan klasikal yang dicapai sebesar $70 \%$ atau 14 siswa yang mendaat nilai mencapai KKM dan 30\% atau 6 siswa yang belum mencapai niali KKM. Nilai terendah 42,5 dan nilai tertinggi 87,5. Dari data tersebut dapat diketahui bahwa ketuntasan klasikal pada siklus I belum mencapa target pada indikator kinerja yaitu $80 \%$, maka penelitian dilanjutkan pada siklus II.

Pada siklus II nilai keteramilan menulis laporan pengamatan siswa kelas V SD N Surakarta tahun ajaran 2017/2018 menunjukkan adanya peningkatan kembali. Hasil nilai keterampilan menulis laporan pengamatan dapat dilihat pada tabel 3. Sebagai berikut:

Tabel 3. Hasil Analisi Nilai Keterampilan Menulis Laporan Pengamatan Siklus II

\begin{tabular}{|c|c|c|c|c|}
\hline \multirow[t]{2}{*}{ Interval } & \multirow{2}{*}{$\begin{array}{c}\text { Nilai Tengah } \\
(x)\end{array}$} & \multirow{2}{*}{$\begin{array}{l}\text { Frekuensi } \\
\text { (f) }\end{array}$} & \multicolumn{2}{|c|}{ Persentase (\%) } \\
\hline & & & Relatif & Kumulatif \\
\hline $60-65$ & 3 & 62,5 & 15 & 15 \\
\hline $66-71$ & - & 68,5 & 0 & 15 \\
\hline $72-77$ & 5 & 74,5 & 40 & 40 \\
\hline $78-83$ & 6 & 80,5 & 30 & 70 \\
\hline $84-89$ & 2 & 86,5 & 10 & 80 \\
\hline $90-95$ & 4 & 92,5 & 20 & 100 \\
\hline \multicolumn{2}{|c|}{ Nilai Tertinggi } & & 95 & \\
\hline \multicolumn{2}{|c|}{ Nilai Terendah } & & 60 & \\
\hline \multicolumn{2}{|c|}{ Nilai Rata-rata } & & 79,88 & \\
\hline \multicolumn{2}{|c|}{ Ketuntasan Klasikal } & & $85 \%$ & \\
\hline \multicolumn{2}{|c|}{ Nilai dibawah 75} & & 3 & \\
\hline
\end{tabular}

Pada siklus II niali rata-rata 79,88 . Ketuntasan klasikal yang dicapai sebesar $85 \%$ atau 17 siswa yang mendapat nilai mencapai KKM dan 15\% atau 3 siswa yang belum mencapai nilai KKM. Nilai terendah 60 dan niali tertinggi 95. Hasil nilai keterampilan menulis laporan pengamatan pada siklus II meningkat dan telah mencapai indikator kinerja yaitu $80 \%$ dan siswa telah mencaai nilai $\mathrm{KKM}$, oleh karena itu peneliti mengakhiri tindakan dalam pembelajaran menulis laporan pengamatan.

Hasil pelaksanaan tindakan setiap siklus maka dapat di simpulkan bahwa penerapan model Think Pair Share berhasil meningkatakan keterampilan menulis laporan pengamatan pada siswa kelas V SD N Surakarta tahun ajaran 2017/2018. Model Pembelajaran Think Pair Share juga berdampak pada peningkatan nilai kinerja guru serta aktivitas siswa dalam proses pembelajaran. Peningkatan nilai keterampilan menulis laporan pengamatan siswa kelas V SD N Surakarta melalui penerapan model Think Pair Share dapat dibuktikan dengan adanya peningkatan nialai rata-rata dan ketuntasan klasiskal pada setiap siklus.

Tes pratindakan keterampilan menulis laporan pengamatan, diperoleh nilai ratarata kelas 60,28, masih kurang dari yang telah ditetapkan. Sedangka presentase siswa yang nilainya tuntas hanya 7 siswa atau $35 \%$, sedangkan $65 \%$ atau 18 siswa lainnya masih belum memenuhi KKM. Nilai terendah pada tes pratindakan yaitu 30, sedangkaan nilai tertinggi yang diperoleh adalah 85 . Berdasarkan hasil analisis tes patindakan tersebut, indikator kinerja penelitia (80\% atau 16 siswa) belum tercapai, maka dilakukan tindakan yang berupa penelitian tindakan kelas untuk meningkatkan 
keterampilan menulsi lapoaran pengamatan dengan menerapkan model Think Pair Share.

Pelaksanaan siklus I menerapkan model Think Pair Share dalam pembelajaran keterampilan menulis laporan pengamatan. Nilai ketuntasan klasikal mencapai $70 \%$ atau 14 siswa yang dapat mencapai nilai KKM dan $30 \%$ atau 6 siswa yang belum mencapai nilai KKM dengan nilai rata-rata kelas 75. Pada siklus II terjadi peningkatan yaitu ketuntasan klasikal mencapai $85 \%$ atau 17 siswa mencapai nilai KKM dan $17 \%$ atau 3 siswa yang belum menapai nilai KKM dan nilai rata-rata kelas 80 sehingga indikator kinerja penelitian telah tercapai apada siklus II.

Peningkatan keterampilan menulis laporan pengamatan tersebut disebabkan adanya perubahan model pembelajaran yang diterapkan oleh guru. Pada kondisi awal guru belum menerapkan model pembelajaran Think Pair Share atau dalam pembelajaran menulis laporan pengamatan siswa kelas V SDN N di Surakarta tahun ajaran 2017/2018. Setelah menerapkan model Think Pair Share keterampilan menulis laporan pengamatan siswa meningkat. Hal ini dipengaruhi oleh terlaksananya urutanurutan model pembelajaran Think Pair Share serta tahapan-tahapan menulis, yaitu prapenulisan, penulisan, dan pasca penulisan. Hal tersebut memungkinkan siswa belajar dari teman secara aktif dalam semua tahapan atau proses penulisan, siswa belajar dari teman dalam kelompoknya maupun diskusi untuk membantu mencari kesalahan, memberi saran maupun masukan pada tulisan teman.

Peningkatan pada nilai keterampilan menulis laporan pengamatan siswa kelas $\mathrm{V}$ SD N Surakarta meningkat pula pada nilai rata-rata kinerja guru dan aktivitas siswa pada siklus I dan siklus II. Pada siklus I kinerja guru termasuk dalam kategori baik dengan skor rata-rata 2,9 dan meningkat pada siklus II menjadi 3,57 masuk dalam kategori sangat baik. Sama halnya dengan aktivitas siswa yang mengalami peningkatan dengan perolehan skor pada siklus I yaitu 2,58 masuk kategori baik dan meningkatat pada siklus II menjadi 3,14 masuk kategori sangat baik. Berdasarkan hasil tersebut menunjukkan bahwa siswa menjadi lebih aktif untuk berpartisipasi dalam pembelajaran keterampilan menulis laporan pengamatan. Peningkatan nilai keterampilan menulis laporan pengamatan siswa dengan diterapkannya model Think Pair Share juga berdampak pada peningkatan kinerja guru dan aktivitas siswa yang dapat meingkatkan partisipasi peserta didik.

Hal tersebut didukung oleh penelitian Sari (2017) yaitu penerapan model Think Pair Share untuk meningkatkan keterampilan menulis deskripsi pada siswa kelas IV SDIT di Boyolali juga baik dan mengalami peningkatan. Pada hasil pratindakan ketuntasan klasikal yang didapat yaitu $39 \%$ kemudian meningkat menjadi $61 \%$ dan pada akhir penelitian presentase ketuntasan klasikal menjadi sebesar $89 \%$.

Oleh karena itu dapat dikatakan bahwa penerapan model Think Pair Share tepat dipergunakan untuk meningkatkan keterampilan menulis laporan pengamatan dan kualitas beajar pada siswa kelas V SD Surakarta tahun ajaran 2017/2018.

\section{SIMPULAN}

Berdasarkan hasil penelitian tindakan kelas yang telah dilaksanakan selama dua siklus dapat disimpulkan bahwa model Pembelajaran Think Pair Share dapat meningkatkan keterampilan menulis laporan pengamatan pada siswa kelas V SD N Surakarta tahun ajaran 2017/2018. Hal ini ditunjukkan dengan ketercapaian persentase ketuntasan nilai keterampilan menulis laporan pengamatan pada tahap pratindakan yaitu 35\% dengan nilai rata-rata 60,28 meningkat pada siklus I menjadi $70 \%$ dengan ratarata 72,5 , dan pada siklus II menjadi $85 \%$ dengan rata-rata sebesar 79,88. 


\section{DAFTAR PUSTAKA}

Sari, MY. (2017). Penerapan Model Kooperatif Tipe Think Pair Share untuk Meningkatkan Keterampilan Menlis Deskripsi pada Siswa Kelas Kelas IIIA SDIT di Surakarta Tahun Ajaran 2016/2017. Surakarta: UNS Press.

Dalman. (2015). Keterampilan Menulis. Jakarta: PT Raja Grafindo Persada

Tarigan. (2008). Menulis Sebagai Suatu Keterampilan Berbahasa. Bandung: Angkasa

Kusumaningsih, T.S., dkk. (2013). Terampil Berbahasa Indonesia.Yogyakarta: C.V Andi Offset

Nurgiyantoro, B. (2013). Penilaian Pembelajaran Bahasa Berbasis Kompetensi. Yogyakarta: BPFE Yogyakarta

Hamdayama, Jumanta. (2015). Model dan Metode Pembelajaran Kreatif dan Berkarakter. Bogor: Ghalia Indonesia

Fathurrohman, M. (2015). Model-model Pembelajaran Inovatif. Yogyakarta: Ar-Ruzz Media 